\title{
The Influence of Potassium on the Yield and Sucrose Content of Sugarcane
}

\author{
George Samuels and Pablo Landrau, Jr. ${ }^{1}$
}

\section{INTRODUCTION}

Sugarcane is mainly grown for the production of sugar. The quantity of sugar produced per acre depends not only on the tonnage of cane produced, but also on the sucrose content of the cane. Increasing the sucrose content of the sugarcane by even a small fraction of a percent will appreciably increase the profit obtained by the cane grower.

Say a field produces 50 tons of millable cane per acre, with a mean sucrosepercent-cane concentration of 12 percent. This gives 120 hundredweights of sugar per acre. If by use of fertilizer we were to increase the sucrose content of the cane but 1 percent, from 12 to 13, the yield of sugar would be 130 hundredweights per acre. To get the same quantity of sugar per acre from 12-percent cane, it would be necessary to obtain yields of 54.2 tons. Thus, by harvesting 50 tons of 13 -percent cane one grower obtains the same quantity of sugar per acre as another who harvests 54.2 tons of a 12-percent cane, with the added advantage that the latter does not have to pay the labor costs involved in harvesting an extra 4.2 tons of cane. He also receives added benefits from the sugarcane mill, because his cane is higher in sucrose, and likewise a larger share of the sugar profits.

The desire for a "sweeter" cane has given rise to many conflicting and inaccurate statements concerning the use of fertilizers and more particularly about their influence on cane sucrose content. Potassium has received the most attention as the fertilizer element that can raise the sucrose content of the cane. It has become common for cane growers to contend that the use of potash fertilizers produces "sweeter" cane. Many of them use high rates of potash application, even where no increase in cane tonnage could be expected, merely in attempts to increase the sucrose content of the cane.

The results obtained in practice and found in the literature have not clearly defined the role of potassium in influencing cane tonnage and the sucrose content of the cane. It is the purpose of this paper to present and interpret the data on the influence of potassium fertilization on cane yields and sucrose for Puerto Rico, as determined by over 40 years of fertilizer

\footnotetext{
1 Plant Physiologist and Assistant Agronomist, respectively, of the Agricultural Experiment Station, University of Puerto Rico, Rio Piedras, P. R. This paper was presented at the 1953 meeting of the American Society of Agronomy at Dallas, Tex., on Nov. 17, 1953.
} 
research conducted by the Agricultural Experiment Station of the University of Puerto Rico.

\section{POTASSIUM AND GANE YIELDS}

Potassium ranks second in importance as a fertilizer element in Puerto Rico, with nitrogen ranking first. When nitrogen was omitted from the cane fertilizer there was an average reduction of 30 percent in cane tonnage for all soil experiments carried on at this Station; when potassium was omitted the yield reduction averaged only 7 percent; the reduction due to omission of phosphorus was 4 percent.

In table 1 a summary is given of the yield increases attributable to potash applications on all soils of Puerto Rico where field experiments were established. The percentage increase in yield was greatest for the semiarid area. The humid area showed the next greatest increase; the yield increase averaged over 30 percent on the red and yellow and gray-brown podzolic soils of this area. The lowest responses were obtained in the irrigated area where, in some cases, applications of potash actually decreased yields.

The responses in cane tonnage to potash were usually higher than indicated in table 1 , because the data include both plant canes and ratoon crops. The response to potash increased with increasing ratoons. An example of this is given in the following tabulation:

$\begin{array}{lc}\quad \text { Crop } & \begin{array}{c}\text { Percentage increase in yield altributable } \\ \text { to potasla applications }\end{array} \\ \text { Plant cane } & 3.2 \\ \text { First ratoon } & 5.9 \\ \text { Second ratoon } & 5.9 \\ \text { Third ratoon } & 7.1 \\ \text { Fourth ratoon } & 12.8\end{array}$

The data are based on the means of four cane varieties. On this Coloso silty clay the percentage increase from potash application rose from 3.2 for the plant cane to 12.8 for the fourth ratoon, the rate of increase accelerating with each ratoon.

The amount of potash used in fertilizing sugarcane in Puerto Rico varies. Samuels and Capó $(6)^{2}$ found in a survy that an average of 129 pounds of $\mathrm{K}_{2} \mathrm{O}$ per acre was used in the humid area and 73 pounds in the irrigated area. The potash is used almost exclusively as a component of the commercial mixed fertilizer applied to the cane. There are farms in the irrigated area to which no potash has been applied in the past 15 to 25 years, yet the cane shows no significant yield response to potash applications. Bonnet (2), in a 12-year fertilizer experiment, obtained no significant yield response to

${ }^{2}$ Numbers in parentheses refer to Literature Cited, p. 178. 
the use of over 90 pounds of $\mathrm{K}_{2} \mathrm{O}$ per acre on a Vayas clay in the irrigated area. In a similar experiment on the humid area, on a Vega Alta clay loam, significant responses were observed in the past few years to rates greater than 90 pounds $\mathrm{K}_{2} \mathrm{O}$ per acre.

$T_{\mathrm{ABLE}}$ 1.-Percentage changes in sugarcane yield attributable to applications of potash in experiments conducted in different areas and on different soils of Puerto Rico, by the Agricultural Experiment Station, University of Puerto Rico

\begin{tabular}{|c|c|c|c|}
\hline Soil series & Soil group 1 & $\begin{array}{c}\text { Number of } \\
\text { experiments }\end{array}$ & $\begin{array}{l}\text { Mean percentage } \\
\text { increase or decrease } \\
\text { in yield attributable } \\
\text { to potash } \\
\text { applications }\end{array}$ \\
\hline \multicolumn{4}{|c|}{ Humid area } \\
\hline Coloso silt loam & Alluvial & 10 & 11.6 \\
\hline Coloso silty clay & do. & 47 & 12.0 \\
\hline Estación silt loam & do. & 2 & 3.3 \\
\hline Fajardo clay loam & Red and Yellow Podzolic & 5 & 33.2 \\
\hline Moca loam & & 1 & 36.4 \\
\hline Toa silty clay loam & Alluvial & 2 & 3.3 \\
\hline Vega Baja silty clay & do. & 16 & 17.8 \\
\hline Via silty clay & Gray-Brown Podzolic & 2 & 34.0 \\
\hline Weighted mean & & 85 & 14.7 \\
\hline
\end{tabular}

Semi-irrigated area

\begin{tabular}{l|l|l|l}
\hline Coto clay & Yellow-Brown Lateritic & 14 & 6.1 \\
\hline
\end{tabular}

Irrigated area

\begin{tabular}{l|l|r|r}
\hline Aguirre clay & Alluvial & 2 & 6.9 \\
Altura silt loam & do. & 2 & -1.2 \\
Coamo clay & Chernozem & 2 & 1.8 \\
Fraternidad & Reddish Chesnut & 12 & -4.8 \\
Machete clay & Reddish Prairie & 2 & -6.1 \\
Mercedita clay & Reddish Chesnut & 2 & 5.2 \\
\cline { 2 - 4 } \multicolumn{1}{l|}{ Weighted mean } & & 22 & -2.0 \\
\hline
\end{tabular}

Semiarid area

\begin{tabular}{|c|c|c|c|}
\hline Santa Isabel silty clay loam & Planosol & 8 & 24.0 \\
\hline Weighted mean for all soils & & 129 & 11.9 \\
\hline
\end{tabular}

${ }^{1}$ An classified by Roberts (5). See test footnote'2.

2 Each variety and crop counted as a separate experiment. 


\section{POTASH AND SUCROSE-PERCENT-CANE}

The influence of potassium on the sucrose content of sugarcane is related to the yield response of the cane. Samuels, et al. (7) found that a direct linear relationship existed for sugarcane in Puerto Rico between the percentage increase in yield and the percentage increase in sucrose concentration, as both factors were influenced by potash applications. The percentage increase in cane tonnage per acre when potash was applied was plotted against the corresponding increase in sucrose-percent-cane. These data were brought up to date for over 200 experiments and the results are shown graphically in figure 1. They indicate that an increase in sucrose content accompanies increases in cane tonnage. The relationship obtained was highly significant. The equation expressing this relationship was $Y=0.12$

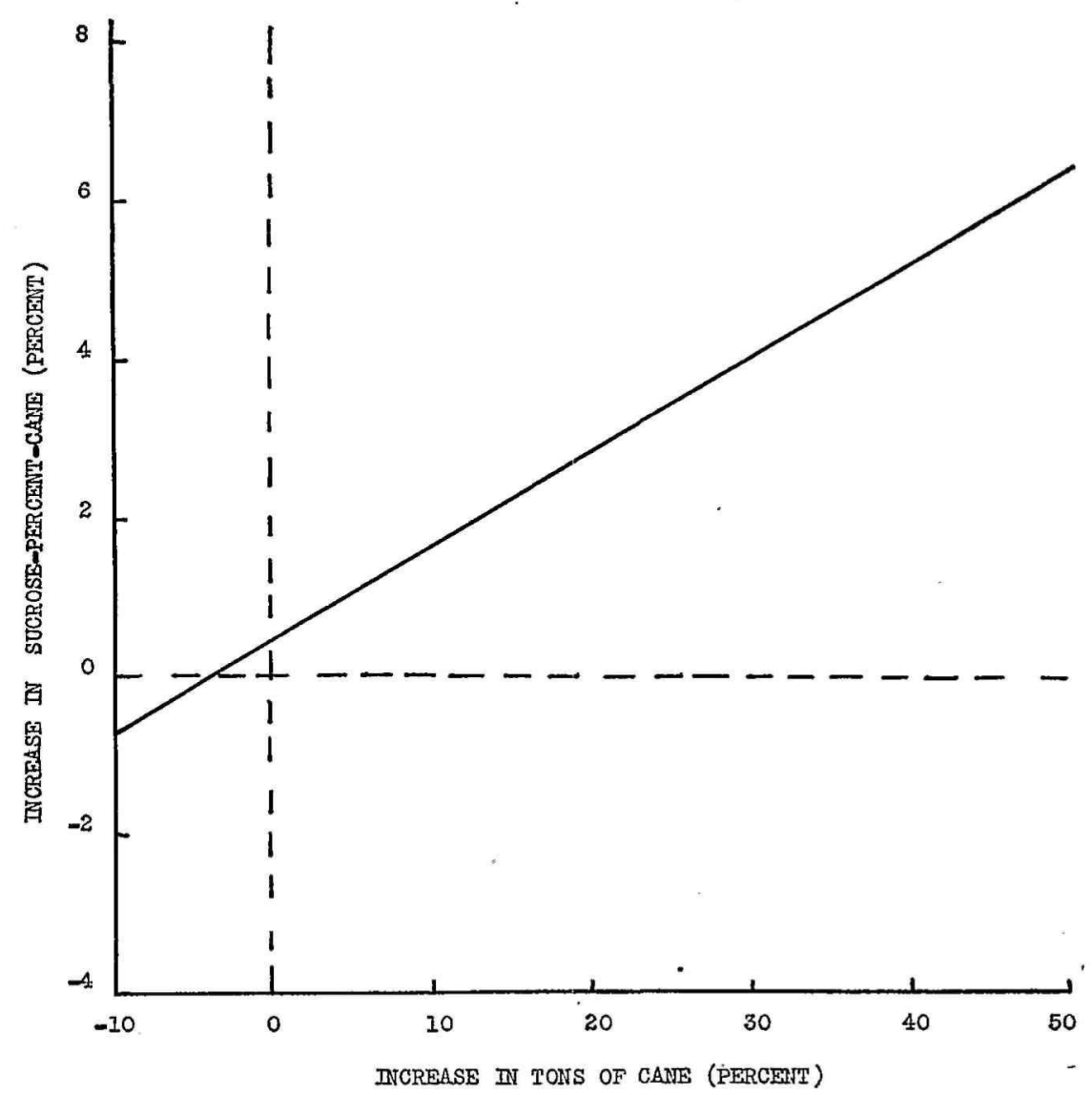

FIG 1.-Relationship between the percentage increase in tons of cane per acre and in sucrose-percent-cane when potash was applied to the sugarcane. 
$x+0.55$, where $Y$ is the percentage increase in sucrose-percent-cane content and $x$ is the percentage increase in tons of cane per acre when potash was applied.

In those cases where yield increases from potash applications were 10 percent or less, the sucrose concentrations were not consistently influenced, and they fluctuated between positive and negative responses. However, when yield increased more than 10 percent, the sucrose content of the cane increased accordingly in response to potash applications. It appears, therefore, that the application of potash fertilizers to sugarcane will not appreciably increase the sucrose content of the cane if it does not increase cane tonnage at the same time. "Luxury" use of potash fertilizers does not make "sweeter" cane unless potash is deficient in the soil for normal cane yields.

Although the cane growers are mainly interested in producing more sugar per acre, the sugarcane factory is also concerned with having more sugar produced per ton of cane. It, therefore, must consider the various components of the term sucrose-percent-cane. The calculation of available $96^{\circ}$ sugar-percent-cane depends on the Brix of the juice, its polarization, and the percentage of juice extracted from the cane by the mill.

Using data from field experiments where potash significantly increased cane tonnage and sucrose concentration, a study was made of the influence of potassium on such individual components of the available $96^{\circ}$ sucrosepercent-cane as polarization, Brix, and percentage of juice extracted. There was a general significant increase in polarization with increased potash applications. Brix and percentage juice extraction showed no significant trends. An example of the influence of potash fertilizers on the components of sucrose-percent-cane is given in figure 2.

Potassium applications mainly influenced the available $96^{\circ}$ sugar-percent-cane content by increasing the polarization value. There was no apparent influence on the total solids in solution (Brix) or on the percentage extraction of the juice that could be attributed to the potash applications.

\section{METHODS OF DETERMINING THE POTASSIUM NEEDS OF SUGARCANE IN THE FIELD}

Potash applications produced increases in sucrose concentration in the cane when corresponding increases in tonnage were obtained. Thus, cane deficient in potassium will suffer in both tonnage and sucrose content. However, showing that a potassium deficiency reduces cane yields and sucrose content is not enough. The next step is to find methods of detecting these deficiencies in the field so that potash may be applied to cane needing this fertilizer, and will not be wasted on cane that has no need for it. As was shown previously not all sugarcane in Puerto Rico needs large applications 
of potash. In fact, certain soils have shown no response to potash, even though cropped to sugarcane for many years without applications of potash.

Several methods have been tried of determining the potash fertilizer requirements for sugarcane in Puerto Rico. Capó (3), utilizing a modification of Mitscherlich's pot-test method with sorghum as the indicator crop, obtained values of $\mathrm{K}_{2} \mathrm{O}$ available for crop use ranging from 125 to 2,961 pounds per acre. Field experiments failed to substantiate this finding by pot tests. Jeffries (4), in a mineralogical study of some of the soils of Puerto Rico, found substantial quantities of a beidellitic type of clay mineral, montmorillenite, and illite, as well as the expected kaolinite clay mineral; however, no immediate difference was apparent in the potassium-fertility status of any soil in which the clay minerals were identified. Bonnet (1) reported on available potash extracted by a 1-percent citric acid solution from the surface soils of Puerto Rico. He found no significant difference between the mean value for the soils of the humid area and for those of the irrigated and semiarid areas.

At present potash deficiency in cane is being detected in the field in Puerto Rico by the use of foliar diagnosis. Decisions as to whether or not potash fertilizers are needed are now being made in some areas of the Island in

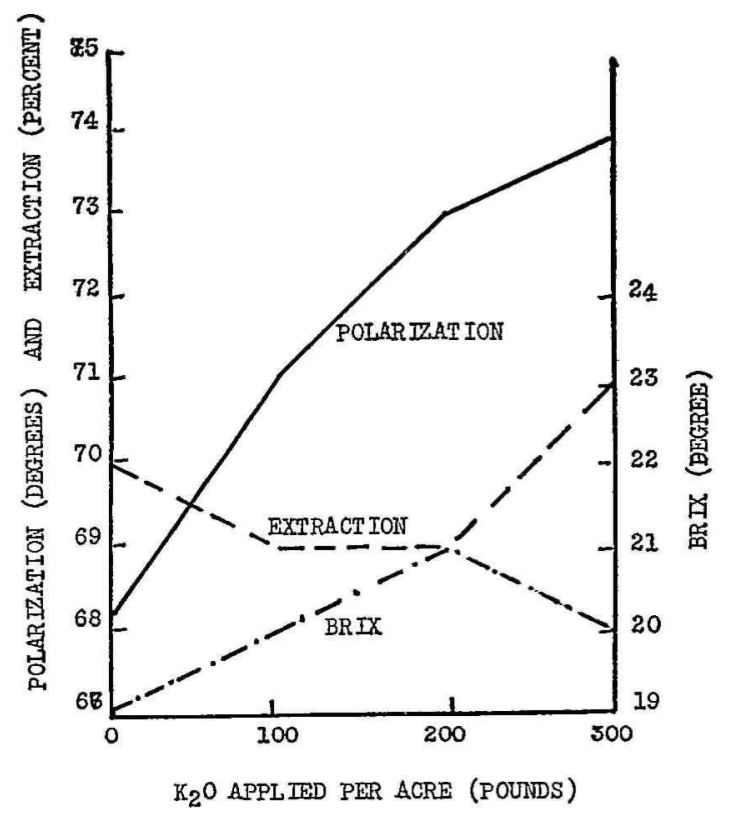

Frg. 2.-Influence of potassium fertilizer applications on Brix, polarization, and percentage juice extraction of sugarcane. 
regular commercial practice, using cane-leaf samples taken at a cane age of 3 months. Potash levels in the leaf indicating deficiency or adequacy have been worked out from detailed experiments conducted by the Agronomy and Horticulture Department of the Agricultural Experiment Station. The experiments were conducted on the leading soil series with the most popularly used cane varieties under treatments with several levels of nitrogen, phosphorus, and potassium. In all treatments where the potash was varied, nitrogen and phosphorus were added at optimum levels.' The leaf samples were taken from replicated plots and yields data were collected when the experiment was harvested. The leaf values were compared with cane yields to determine whether the levels found were associated with significant yield responses.

Leaf-potassium values of 2 percent or more, on a dry-weight basis, were found to be associated with no response to potash fertilizers for all soil areas. Values of 1.75 percent or more generally proved to be an adequate level for which no responses to potash applications could be expected. On

TABLE 2.-Leaf-potassium values for sugarcane from selected experiments and their relation to cane yields and potash applications

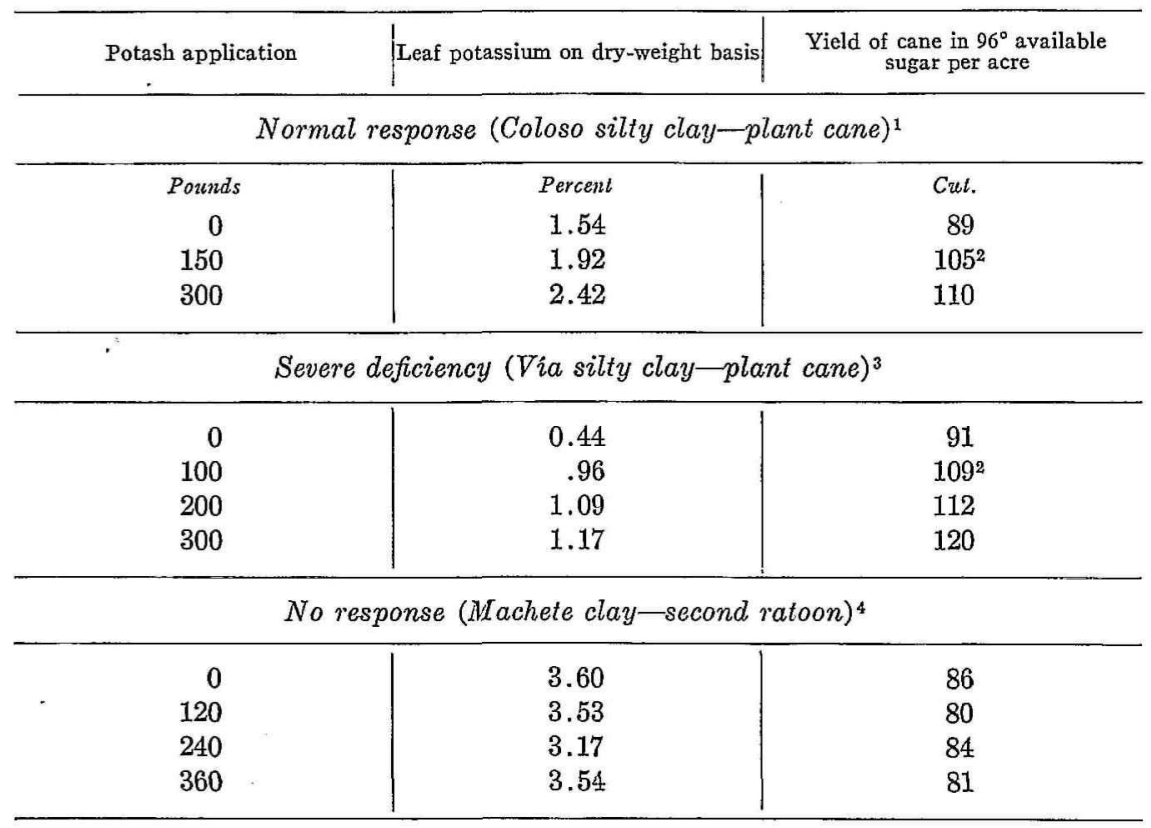

1 The mean of 4 varieties at Central Coloso experiment, Aguadilla.

2 Response significant at 1-percent level over no potash treatment.

${ }^{3}$ One variety at Colonia Santa Teresa experiment, Humacao.

${ }^{4}$ One variety at Colonia Esperanza, Aguirre. 
soils where experiments showed severe potash deficiency, such as the Via silty clay and the Santa Isabel silty clay, the use of rates as high as 300 pounds of $\cdot \mathrm{K}_{2} \mathrm{O}$ per acre failed to raise leaf-potassium levels over 1.80 percent. In table 2, examples are given of three types of conditions encountered in the use of foliar diagnosis for potash with sugarcane: Severe deficiency, normal response, and no response with "Iuxury" consumption.

Although visual evidence of potassium deficiency has been obtained on sugarcane in greenhouse work, it is not normally seen in the field and recognized as such. When deficiences of potassium are evident visually, the cane is usually suffering from very severe deficiencies. However, the foliardiagnosis technique facilitiates the detection of potash deficiency in cane fields where visual symptoms were not apparent, and fertilizer can still be applied to correct the deficiency.

\section{SUMMARY}

Critical analysis of the results of over 200 field experiments with potash fertilizers on sugarcane conducted by the Agricultural Experiment Station of the University of Puerto Rico, covering a wide ranges of cane varieties and soils types of Puerto Rico, revealed the following:

(1) Potash increased cane yields mainly on the red and yellow podzolic soils of the humid area and on a planosol of the semiarid area. There was slight, if any, response to potash in the irrigated area.

(2) The use of potash increased the sucrose concentration of the cane only if cane yields were also increased. Increases of 10 percent or more in tonnage were required if increases in sucrose content were to be expected. A linear relation $Y=0.12 x+0.55$ was obtained where $Y$ was the percentage increase in sucrose-percent-cane and $x$ the percentage increase in tons of cane yielded per acre.

(3) When potash fertilizers significantly influenced the sucrose concentration of the cane, the polarization value of the cane juice increased. Brix and percentage extractability of juice were not appreciably affected.

(4) The use of foliar diagnosis has proven to be of great value in Puerto Rico in determining when to apply potash fertilizers to sugarcane. Leaf values of 2 percent or more, on a dry-weight basis, indicate that no response to potash applications can be expected for soils and varieties in Puerto Rico. Values below 1.80 percent indicate that a response, to potash fertilizers may be expected in the humid areas.

\section{RESUMEN}

Los análisis críticos de los resultados de más de 200 experimentos de campo, llevados a cabo por la Estación Experimental Agrícola de la Uni- 
versidad de Puerto Rico, sobre el uso de los abonos potásicos para la caña de azúcar, los cuales cubrieron una gran diversidad de variedades de caña y de tipos de suelos, demostraron lo siguiente:

(1) La potasa aumentó los rendimientos de la caña, principalmente, en los suelos podzólicos rojos y amarillos de-las áreas húmedas y en un suelo planosol, cuya área era semiárida. Apenas respondió la caña a las aplicaciones de potasa en las áreas bajo riego.

(2) El uso de la potasa aumentó la concentración de la sacarosa, siempre y cuando se aumentaran los rendimientos de la caña. Aumentos del 10 por ciento o más en tonelaje tenían que obtenerse para que se aumentara el contenido de sacarosa. Una relación lineal $Y=0.12 x+0.55$ se obtuvo cuando $Y$ representó el porcentaje de aumento en el por ciento de sacarosa en la caña y $x$ el porcentaje de aumento en toneladas de caña obtenidos por acre. El Brix y el porcentaje de extracción del jugo no se afectaron apreciablemente.

(3) El valor de la polarización del jugo se aumentó cuando la aplicación de los abonos potásicos influyeron significativamente sobre la concentración de sacarosa en la caña.

(4) El uso del diagnóstico foliar ha demostrado ser de gran utilidad en Puerto Rico para determinar cuándo deben aplicarse abonos potásicos a la caña de azúcar. Los valores de un 2 por ciento o más en las hojas (base seca) indican que no se puede esperar que los suelos y las variedades en Puerto Rico respondan a las aplicaciones de potasa. Los valores más bajos de 1.80 por ciento indican que puede esperarse que los suelos y las variedades respondan a la potasa en las áreas húmedas.

\section{LITERATURE CITED}

1. Bonnet, J. A., Chemical data of Puerto Rico soils, Agr. Exp. Sta., Río Piedras, P. R., Res. Bull. 1, 53 p., Apr. 1941.

2. - - Potassium content of Puerto Rican soils as related to sugarcane growing, J. Agr. Univ. P. R., 37 183-94 1953.

3. Capó, B. G., Available nutrient contents of Puerto Rican soils as determined by pot tests; thesis presented to the Faculty of the Graduate School of Cornell University for the degree of Doctor of Philosophy (unpublished), 1942.

4. Jeffries, C. D., Bonnet, J. A., and Abruña, F., The constituent minerals of some soils of Puerto Rico, J. Agr., Univ. P. R., 37 114-39 1953.

5. Roberts, R. C. and party, Soil survey of Puerto Rico, USDA, former B.P.I., in cooperation with Univ, of P. R., Agr. Exp. Sta., series 1936, No. 8, 503 pp. Jan. 1942.

6. Samuels, G., and Capó, B. G., A survey of the agronomic practices in growing sugarcane in Puerto Rico in 1952. International Society of Sugareane Technologists, Agronomy Section, 8th Congress, British West Indies.

7. Samuels, G., Lugo López, M. A., and Landrau, P., Influence of fertilizers on sucrose content of sugarcane, Sugar 47 49-51 Nov. 1952. 